\title{
A Human Victim of Volcanic Eruption of Mt. Asama in 1783
}

\author{
Iwataro MORIMOTO \\ Department of Anatomy, St. Marianna University School of Medicine
}

\begin{abstract}
Four hundred and sixty-six people were buried at Kambara Village of Province Kozuke (old name of Gunma Pref.), Japan, under the glowing avalanche of volcanic debris due to the violent eruption of Mt. Asama in 1783 (the 3rd year of Temmei), which was followed by the so-called "big famine of Temmei" in the eastern half of this country. Well known were those two ladies buried alive under the flow of volcanic debris at the foot of the stone stairs to Kannon-do temple on a hill at the back of the village who were found in 1979. The present paper is a record of another man also killed by the flow of volcanic debris there. Suffering from chronic osteoarthritis in his left elbow, he was working for Emmyoji Temple at Kambara in those days and killed by the debris flow without warning. His skeleton was excavated at the ruins of this old temple in 1987. He was lying on the right half of his face as well as on his belly with the left arm and right leg extended but the right arm and left leg flexed. His right humerus, radius and ulna were fractured together in their shafts at a blow of a rushing stone in the debris. The findings indicated that a sudden attack of the flow of pyroclastic debris at low temperatures was the death of him. He was placed third among the human victims of the 1783 volcanic activity of Mt. Asama whose skeletons were preserved well and examined in details.
\end{abstract}

Keywords Japanese skeleton, Mt. Asama, Volcanic disaster, Famine of Temmei, Edo period

\section{Introduction}

A human skeleton was excavated at Kambara of Tsumagoi Village, Agatsuma County, Gunma Prefecture, Japan, in 1987 under the direction of Mr. Eiji MATSUSHIMA, a leading archaeologist in this region. The author went to Kambara and examined the skeleton carefully. The skeleton was of an adult Japanese male who was killed by the flow of volcanic debris at a low temperature due to the violent eruption of Mt. Asama in 1783 (the 3rd year of Temmei), which was followed by the so-called "big famine of Temmei" in the eastern half of this country (Temmei is one of imperial era names in Japan, covering from 1781 to 1789).

The present paper is a record of observations on the skeleton of the victim of the volcanic activity of Mt. Asama in 1783 which was unearthed there in 1987. 


\section{Background}

Old Kambara in the Edo period was a small village situated in the northern skirts of $\mathrm{Mt}$. Asama $(2,542 \mathrm{~m})$, being about $900 \mathrm{~m}$ above sea level and horizontally $12 \mathrm{~km}$ apart from the crater. The village developed as a relay station near the crossing of two main roads: one was Mihara road connecting Kutsukake post-station town (old name of Naka-Karuizawa) along the Nakasen-do major road with Kusatsu hot spring resort via Mihara village, and another was OmaeSugao road connecting Takasaki castle town along the Nakasen-do with Ueda castle town along the Hokkoku-kaido major road via both Sugao and Torii mountain passes. On August 5 th, 1783, the Kambara village of 93 houses was unexpectedly crushed under the glowing avalanche of volcanic debris due to the gigantic explosion of Mt. Asama. The destruction was instantaneous and so devastating that 466 out of its 597 inhabitants $(78.1 \%)$ as well as 170 out of 200 horses $(85.0 \%)$ were killed. Reportedly only 93 persons running away onto a hill at the back of the village, where a Kannon-do (Buddhist temple for the Goddess of Mercy) was built, were spared.

This gigantic eruption, called "Asama burning of Temmei", began with a moderate eruption on May 9th, 1783. The second eruption occurred in June, the third and the fourth in July at brief irregular intervals. Mt. Asama went into the fifth violent eruption during three days from August 2nd to 4 th. In this case, the volcano exploded and magma flowed out of the central vent, making a pyroclastic flow called "Agatsuma Flow" on its northeastern flanks. The following eruption in question occurred on August 5th, sending a vast flow of pyroclastic materials called "Kambara Flow", which destroyed and covered the Kambara village completely on the northern skirts of the volcano and reached Agatsuma river
$15 \mathrm{~km}$ distant from the crater. Finally the volcano ceased eruption after sending a sticky lava flow called "Oni-Oshidashi" streaming down its upper northern flanks.

The glowing avalanches of volcanic debris rolled into the Agatsuma river and made a mixture of water and volcanic debris that rushed far down the valley, and was overwhelming all in its path. The mudflows and accompanying floods raced down the valleys of both Agatsuma and Tone river channels, and killed 1,624 or more people. Many human bodies were carried away by a long and strong stream of the Tone river and drifted ashore to Maebashi castle town (present-day seat of the Gunma prefectural government), and farther to Edo City (Edo is the old name of Tokyo). The citizen of Edo in those days built stone monuments to mourn the victims who went downstream to this great city in summer of 1783 , such as seen at Buddhist temples of Zen-yo-ji in Edogawa-ku and ShibamataTaishakuten in Katsushika-ku, Tokyo, at the present time.

The houses and people buried under the flow or glowing avalanche of volcanic debris at Kambara have been recently excavated archaeologically since the August of 1979, and a dire disaster of this relay station and a rebuilding of the village after the tragedy are now widespread by such popular references as written by HAGIWARA (1975), GUNMA-BUNKA-NO-KAI (1976), GUNMA-NO-REKISHI-MONOGATARIKANKO-KAI (1979), ASAMA-SANROKUMAIBOTSU-SONRAKU-SOGO-CHOSA-KAI (1981), KOIZUMI (1986), ODA (1988) and OISHI (1986, 1990).

As for the skeletal remains of the human victims, five have been discovered. Skeletons of an adult and a child were found by chance at Toka-no-Kubo of Kambara in March of 1976. They were considered to be of the victims of the flow of volcanic debris due to the explosive erup- 
tion of Mt. Asama in 1783. The skeletons were, without any scientific examinations, reverently reburied at Kambara after inspection by policemen. Another adult skeleton was discovered during excavations by the members of the abovementioned research group at the same Toka-noKubo in summer of 1979. This skeleton was, however, so badly preserved that neither age nor sex was known. Well known were two other skeletons found also by the same research group members, which fell in a heap at the foot of the stone stairs to Kannon-do temple on a small hill at the back of the village of Kambara. They were regarded as the skeletons of an old and a mature ladies by Prof. Ken FURUKAwA of the Department of Forensic Medicine, Gunma University, Maebashi. ASAHI-SHIMBUN-SHA (1987) reported in the Weekly Asahi Encyclopedia that a motherdaughter relation between the two lady skeletons discovered was morphologically established by Prof. emeritus Hisashi SuZUKI of the Department of Anthropology, University of Tokyo, who restored their faces and heads to the original state based on their cranial forms. It seemed that the daughter was beginning to run up the stone stairs to the Kannon-do on the hill to escape from the avalanche of volcanic debris, probably carrying her old mother on her back. They were, however, unfortunately killed by the flow of debris moving down the volcanic slopes at speeds exceeding $40 \mathrm{~km}$ an hour at the foot of the stairs of 50 steps, in striking contrast with some people alive on the upper 15 steps which were not damaged at all by the volcanic debris.

\section{Discovery of A New Victim}

The skeleton of an adult male in the prime of life was newly discovered in August 9th of 1987 when the ruins of old Emmyoji temple at Kambara was archaeologically excavated by the Board of Education of Tsumagoi Village under the direction of Mr. Eiji MATSUSHIMA. The
Emmyoji temple has been believed to be buried under the growing avalanche of volcanic debris due to the gigantic explosion of Mt. Asama in 1783. The skeleton lay beneath the layer of debris flow, about $5.5 \mathrm{~m}$ under the present-day surface of the earth. Since the skeleton was discovered nearby the northern end of a crushed wooden shed which seemed to be attached to the main building of the old temple, the man must have been killed immediately after running out of the shed. His feet, toward the volcano Asama, were a little more raised than his head. As shown in Figs. 1 and 2, he was lying on the right half of his face as well as on his belly, with his left arm extended over his head and his right leg extended in a straight line, but his right arm and left leg flexed to the very limits, i.e. assuming a posture as seen at the moment of a left-handed hook shot made on the run in playing basketball. His left hand seemed to get a good grasp of the earth, while his right hand was forced to turn the palmar surface upward and to point the finger tips to his right foot. Because his right arm was extremely flexed at his elbow joint, his right humerus, radius and ulna were completely fractured together in their shafts probably at a blow of a rushing stone in the debris flow. But this was mere guesswork, since the stone in question could not be found there. Owing to this accident, only the lower fragments of the radius and ulna fractured were secondarily forced to take an excessively pronated position, which was probably due to their deviation or severance from the upper part of the bones fractured under the influence of a local pressure caused by the volcanic debris flow. The ankle and feet of his left leg flexed were brought beneath the pelvis, whereas his right leg extended was slightly abducted at the hip joint, suggesting that the trunk of his body was given a good push by the debris flow on the right side. This agreed with a geological observation that the volcanic debris flow ran not to the northern but 


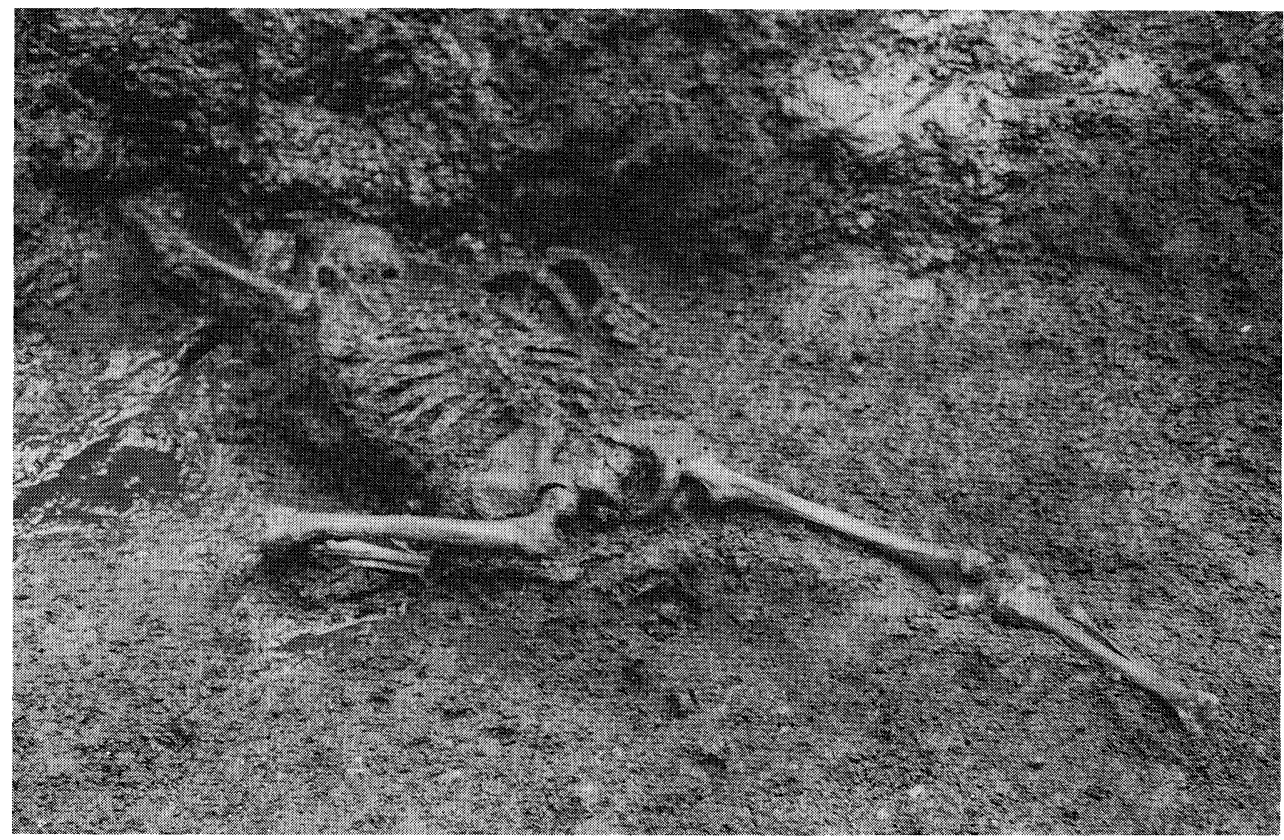

Fig. 1. Skeleton of a human victim of volcanic eruption of Mt. Asama in 1783 from Kambara. Note the victim's posture of refuge from the glowing avalanche of debris in extraordinary emergencies.

to the northwestern direction there. The above findings and situation were sufficient to give an explanation that an adult male working for the temple was killed by the volcanic debris flow due to the 1783 explosive eruption of Mt. Asama without warning. In addition, a small amount of his hairs tied up into a knot were left in poor preservation near the parietal region of his skull.

The whole skeleton of the human victim buried deep under the debris flow was in a good state of preservation. This was mainly attributed to the facts that the debris flow which engulfed the Kambara village in 1783 was, according to NAKAMURA et al. (1987), composed of the volcanic materials at lower temperatures, and that not acid but neutral rain-water sinking into the earth was slowly running between the layer of volcanic debris deposited and the old surface of the grounds of the Emmyoji temple where the skeleton in question was lying.
Immediately after the author's examinations, the skeleton was laid to rest at the cemetery of Kambara mournfully by the present-day villagers who regarded it as of one of their direct ancestors.

\section{Physical Characteristics of the Skeleton}

Almost all the bones of the skeleton remained were mostly in a good condition with a wellpreserved internal architecture. The results of measurements and observations were as follows.

(a) The skull

Anterior and right lateral views of the skull were given in Figs. 3 and 4. The skull was relatively large. The lower and anterior part of the frontal squama was markedly sloping. The glabella was prominent, but the root of the nose was deeply set. The zygomatic arches were heavy, the mastoid processes were large, and the external occipital protuberance was developed well. The 


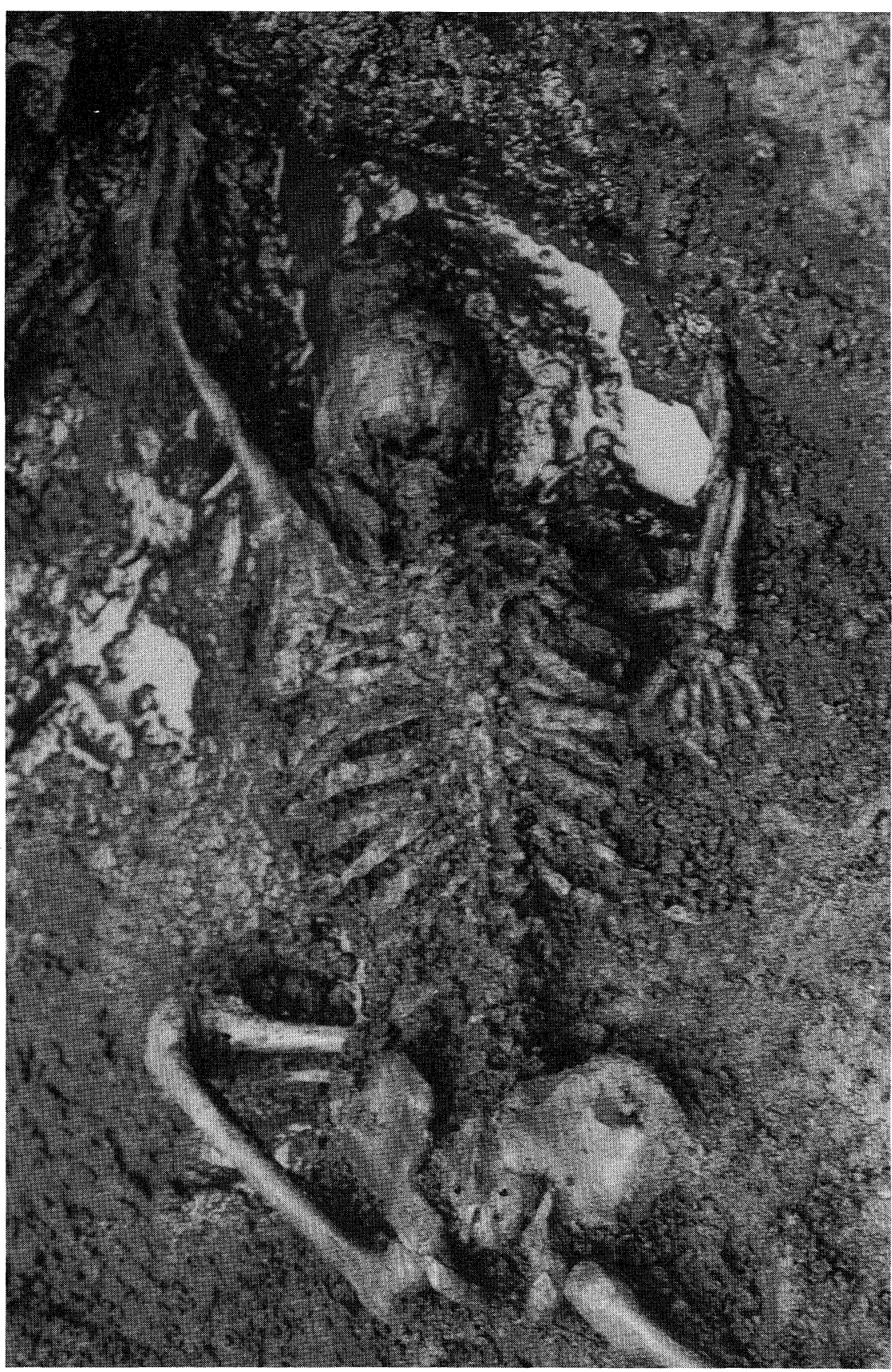

Fig. 2. Skeleton of the same victim as shown in Fig. 1, making the arrangement of the bones of the head, neck, trunk and arms clear. 


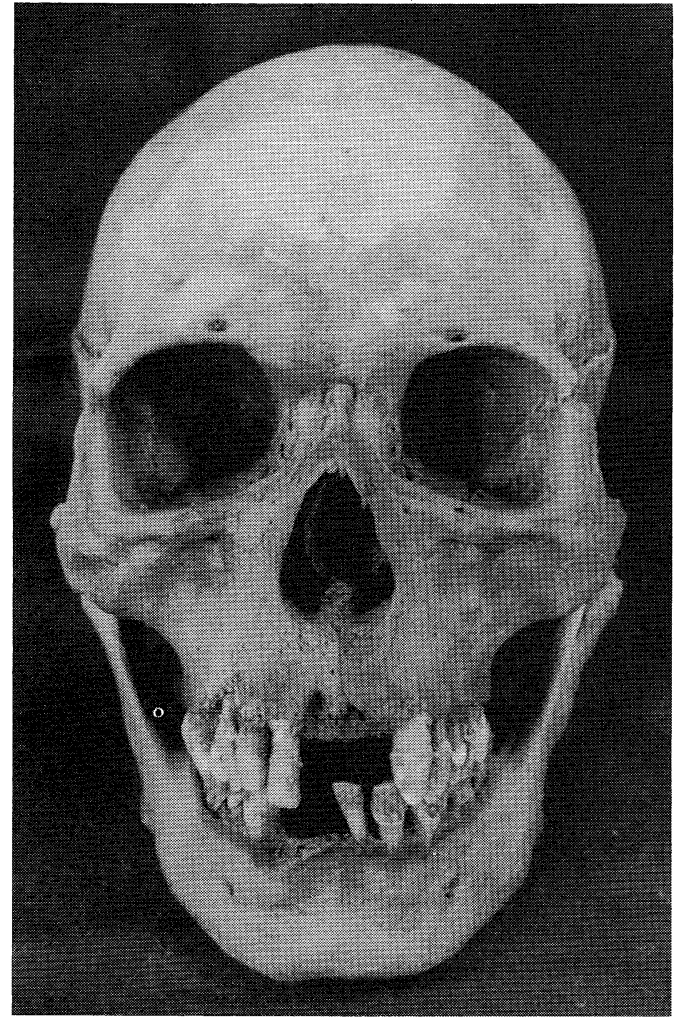

Fig. 3. Anterior view of the skull.

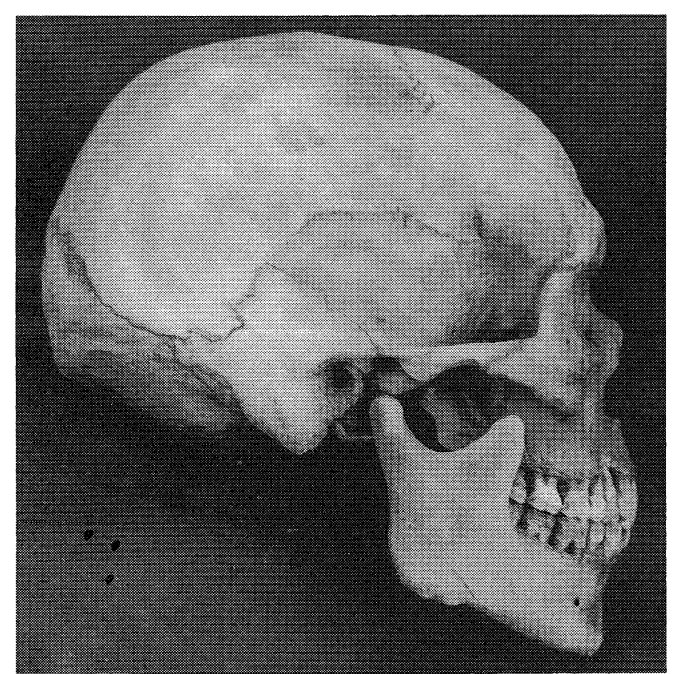

Fig. 4. Right lateral view of the skull. mandible was great in size and had broad rami. All of these indicated that the skull belonged to the male sex. The principal sutures of the skull vault were completely closed on the inner table, but closure mostly remained imcomplete on the outer table, suggesting that the age of the individual reached the prime of life.

The measurements and indices of the skull

Table 1. Measurements and indices of the skull obtained

Item with MARTIN's number

Measurement (mm) or index

1 Maximum length of vault

193

8 Maximum breadth of vault

9 Minimum frontal breadth

11 Biauricular breadth 124

26 Median sagittal frontal arc

27 Median sagittal parietal arc

28 Median sagittal occipital arc

29 Median sagittal frontal chord

109

30 Median sagittal parietal chord

121

31 Median sagittal occipital chord

23 Horizontal circumference of vault

537

45 Bizygomatic breadth

133

46 Middle facial breadth

47 Total facial height

51 Orbital breadth

52 Orbital height

54 Nasal breadth

61 Alveolar breadth of maxilla

68(1) Mandibular length

69 Symphyseal height of mandible

69(3) Thickness of mandibular body

70a Height of mandibular head

71a Min. breadth of mandibular ramus

$8 / 1$ Length-breadth index of vault

78.6

48.0

$54 / 55$ Nasal index

95.5

47/45 Total facial index (KOLLMANN)

129.6 
obtained were given in Table 1. The lengthbreadth index of the cranial vault showed that the skull was of hyperdolichocranic type. Of the two total facial indices obtained, one indicated that the facial skeleton belonged to the hyperleptoprosopic type (KOLLMANN), while another to the orthoprosopic type (VIRCHOW). The orbital index was of mesokonchic type and the nasal index was of mesorrhinic. A slight alveolar prognathism could be recognized. Presence and absence of nonmetric cranial variants were tabulated in Table 2 .

The occlusal view of the upper and lower teeth was shown in Fig. 5. The formula of the teeth observed was given in the following.

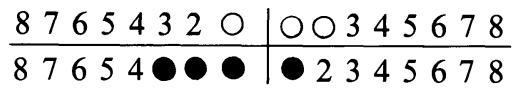

In the formula, the numbers referred the permanent teeth left in the alveolar sockets, while the signs of black and white circles showed closed and open alveolar sockets, respectively. The dental occlusion belonged to the most common

Table 2. Presence and absence variation of nonmetric cranial variants

\begin{tabular}{lcc}
\hline \multicolumn{1}{c}{ Item } & Left & Right \\
\hline Medial palatine canal bridging & A & A \\
Pterygospinous foramen & A & A \\
Hypoglossal canal bridging & A & A \\
Condylar canal missing & P & P \\
Foramen of HUSCHKE & A & A \\
Supraorbital foramen & P & P \\
Accessory infraorbital foramen & A & A \\
Mylohyoid bridging & A & A \\
Accessory mental foramen & A & A \\
Metopism & & A \\
Transverse zygomatic suture trace & A & A \\
Inca bone & & A \\
Parietal notch bone & A & A \\
\hline
\end{tabular}

A: absent; P: present type of psalidodontia, where the upper anterior teeth slightly overlapped the lower ones. The loss of the lower first and second incisors and canine on the right side and the lower first incisor on the left side with subsequent healing were probably attributed to periodontal disease, such as pyorrhoea, although no dental caries was found in the other remaining teeth. The upper and lower incisors, canines and premolars showed a slight degree of wear, whereas all the molar teeth showed a high degree of dental attrition, their dentines being moderately exposed. Almost all the teeth showed both slight alveolar resorption through periodontal disease and considerable deposit of dental calculus, especially on their

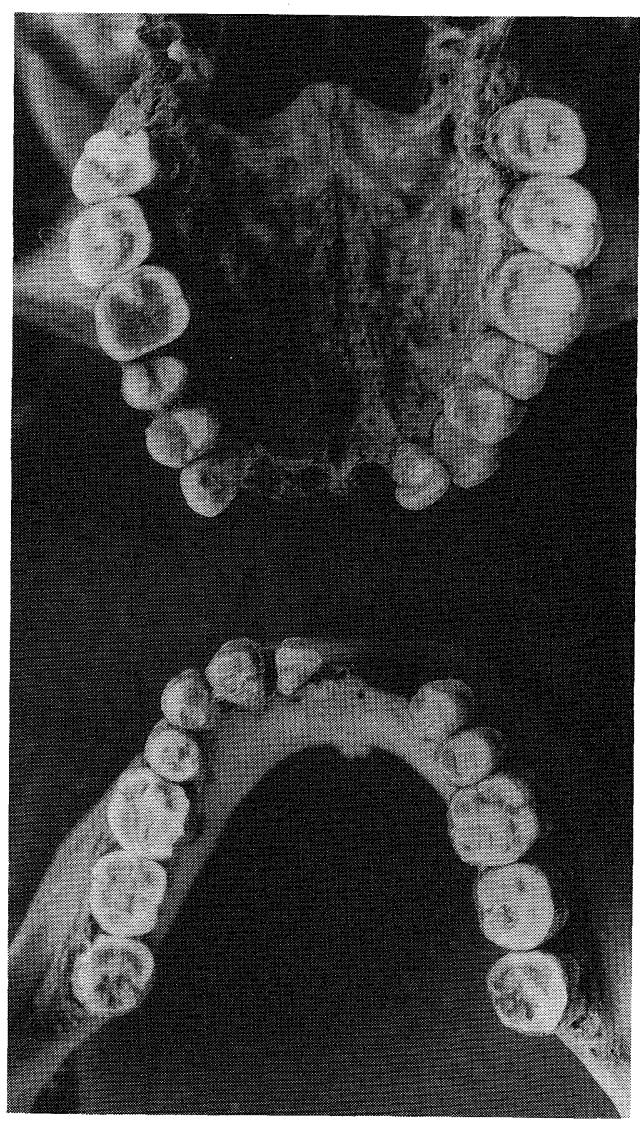

Fig. 5. Occlusal view of the upper and lower teeth. 
lingual and buccal sides.

(b) The postcranial bones

In the pelvis, the base of the sacrum was relatively narrow, the acetabulum was distant from the symphyseal surface by approximately its own diameter, the greater sciatic notch was $\mathrm{J}$-shaped, and the subpubic angle was relatively acute, similar to the angle between the index and middle fingers when spread. All these revealed that the pelvis belonged to the male sex. The symphyseal surfaces of the pubic bones showed a metamorphosis evaluated in terms of combinations of I-5, II-5 and III-5 at the stages of three components shown by BROTHWELL (1981). By referring to his table, though based on young American males, the formula could be translated into the modal frequencies of 31,32 and 38 years. It followed from these three age estimates that the individual was probably aged 34 or more years at death.

In the left humerus, the maximum length was $278 \mathrm{~mm}$ and the thickness index (the ratio of the minimum diameter to the maximum diameter in the middle of the shaft) was 75.0. The platymeric index of the right femur indicated a hyperplatymeric value of 70.6 , whereas the pilastric index of the same bone was 103.6 indicating little pilaster formation. The cnemic index of the right tibia was 62.9 , indicative of platycnemic type. The maximum lengths of the right tibia and femur were $316 \mathrm{~mm}$ and $381 \mathrm{~mm}$, respectively. Using the tibial and femoral lengths, the stature of this male individual could be calculated as $152.1 \mathrm{~cm}$ by the application of PEARSON's formula.

Bony lipping and spur formation were found at the anterior margins of the 9th and 10th thoracic and the 2nd, 3rd and 4th lumbar vertebral bodies which could be indicative of spondylarthrosis with moderately severe degenerative changes. Fig. 6 exhibits the changes in the thoracic and lumbar vertebrae observed.
The right humerus, radius and ulna were, as mentioned above and shown in Fig. 8, completely fractured in their shafts together at a violent blow of a rushing stone in the volcanic debris flow. The fracture lines of these long bones were spiral. Because the fracture of the radius was of comminuted type, small lateral fragments of bone on the fracture line had been lost. In the left elbow joint, on the other hand, bony lipping occurred at the margins of the humeral condyle, radial head and ulnar troclear notch, with a slight roughening of the articular surfaces suggestive of chronic osteoarthritis. Thus the useful range of flexion-extension in the left elbow joint was, as shown in Fig. 7, about 50 degrees at angles from 60 in its full flexion to 110 degrees in its full extension.

\section{Discussion}

Japan is volcanic islands on the west of the Pacific and has many active volcanoes. Ten per cent of the world's active volcanoes are, according to KNAPP (1989), to be found in Japan. People who live in valleys on the sides of volcanoes are in danger from mudflows. One way to be prepared is to look at past eruptions and learn the lessons that they give. Although volcanic eruptions have killed a large number of people in Japan, little has been known on the human victims buried under a thick layer of volcanic mud or debris flow. As far as the author knows, the sole report of this was originally the abovementioned book written by ASAMA-SANROKUMAIBOTSU-SONRAKU-SOGO-CHOSA-KAI and TOKYO-SHIMBUN-HENSHUKYOKU-HODOBU in 1979, which gave wider publicity to the skeletons of those who were killed at Kambara by the 1783 explosive eruption of Mt. Asama. Of 466 human victims killed by the volcanic debris flow there, only five skeletons have been discovered. Three of the five were in a poor state of preservation and not subjected to any scientific examinations. 


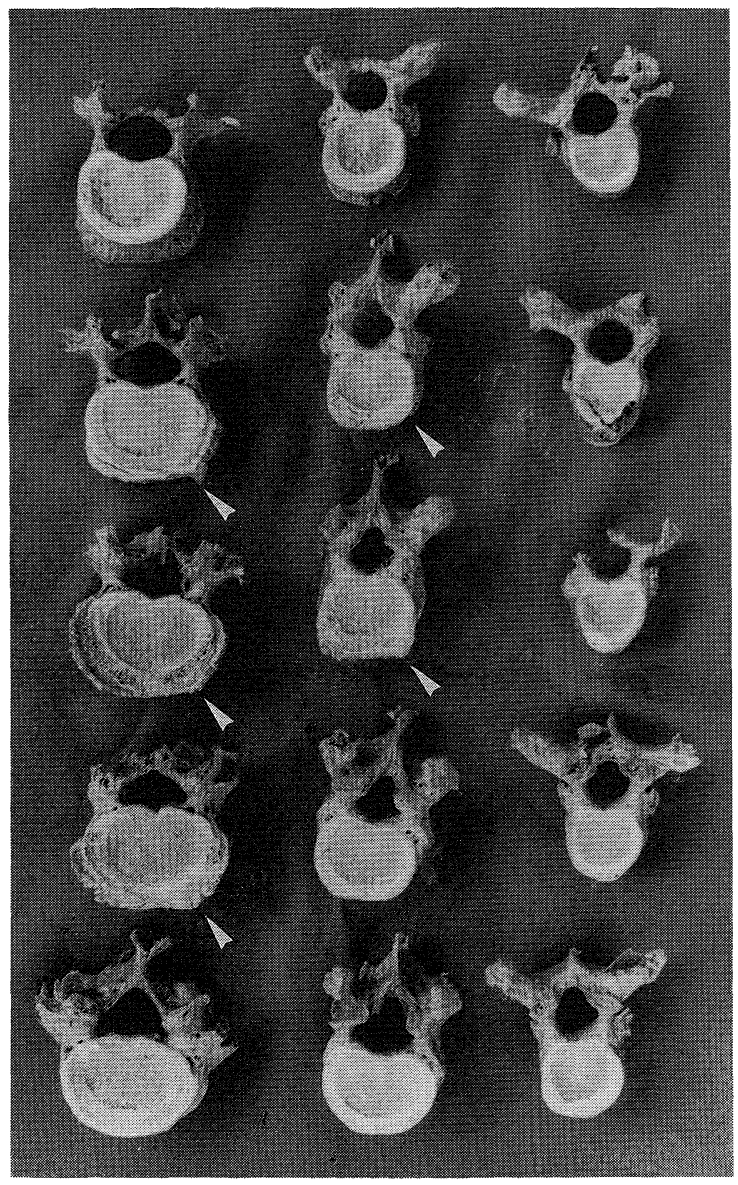

Fig. 6. Thoracic and lumbar vertebrae, showing osteophytic lipping on the upper surfaces of the $\mathrm{Th}_{9-10}$ and $\mathrm{L}_{2-4}$ vertebral bodies (arrows).

Well known are the other skeletons of two ladies who fell down one upon another at the foot of the stone stairs to Kannon-do temple on a hill behind the village. Hence, the human male skeleton from Kambara reported in this paper was placed third among those human victims of the 1783 eruption of Mt. Asama whose skeletons were preserved well and examined in detail.

In 79 A.D., Mt. Vesuvius erupted and buried the nearby town of Pompeii, Italy. This is probably the world's most famous volcanic disaster. Both Reader's Digest's History of Man (1973) and
Times Atlas of Archaeology (1988) described that the volcanic ash killed some one-fifth of about 10,000 Pompeii's inhabitants. Choking gas from Vesuvius asphyxiated the inhabitants of Pompeii as they tried to flee the falling ash. The ash hardened round its victims to form a mould, which in modern times has been filled with plaster and drug out of the ash. Many were found lying in cellars or bedrooms where they had taken refuge; others had fallen in the open while seeking to escape over the deep banks of lapilli. What was discovered at Kambara in 1987 was not a plaster 

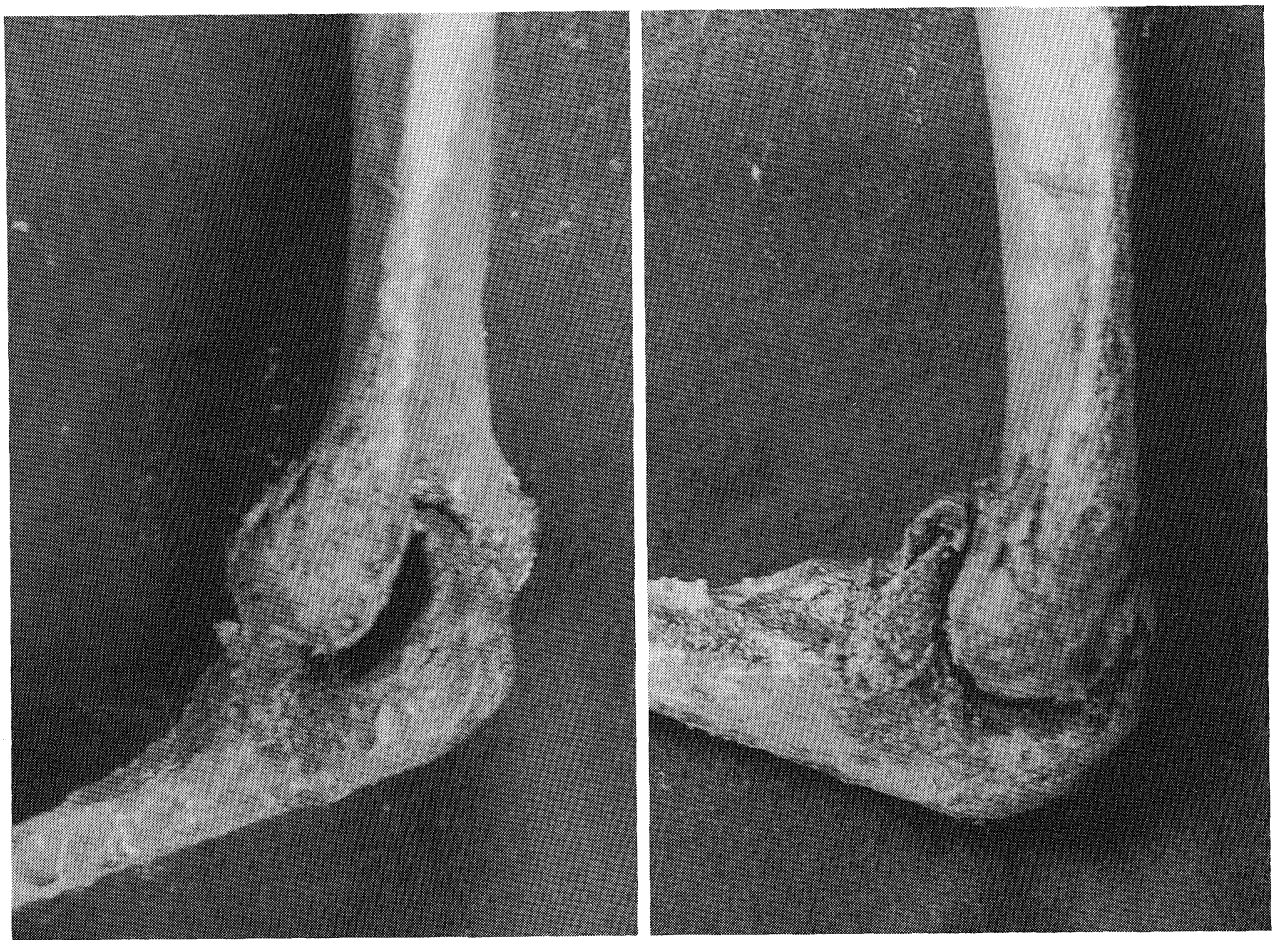

Fig. 7. Lateral view of the left humero-ulnar joint, restricted in its extension (left) and flexion (right) resulting from chronic osteoarthritis.

model imprinted in the volcanic ash, but the human skeleton itself which was buried deep under the layer of the volcanic debris from Asama in 1783. Since the victim was caught, fractured and killed by the debris flow immediately after his rushing out of the shed attached to Emmyoji temple, it is undoubted that the volcanic debris flow attacked him without any warning and in a matter of seconds, and that he had no chance to react or to escape. The author's view could be endorsed by the victim's skeleton which confusedly assumed a posture as seen at the moment of a left-handed hook shot made on the run in playing basketball. Much the same posture was, according to KOHARA et al. (1971), adopted reflexly by a human child of three years who was pressed to death by a falling rock separated from the ceiling of Tochibara rock shelter, Nagano Prefecture, Japan, in the earliest stage of the Jomon period, i.e. estimated 8,650 years B.P.

Because the adult male victim at Kambara suffered from chronic arthritis in his left elbow, the extension of his left upper arm was restricted in his physical behavior for refuge on pressing emergencies. Nevertheless, his left hand get a good grip on the earth. On the other hand, he failed to grasp the earth by his right hand, because his right upper arm flexed was struck so strongly with a rushing stone that his right humerus, radius and ulna were fractured together in their shafts. This also furnished evidence that he had no chance to escape from the attack by the volcanic debris flow.

The hyperdolichocranic skull, the slight prognathism and the hyperplatymeric femur as 


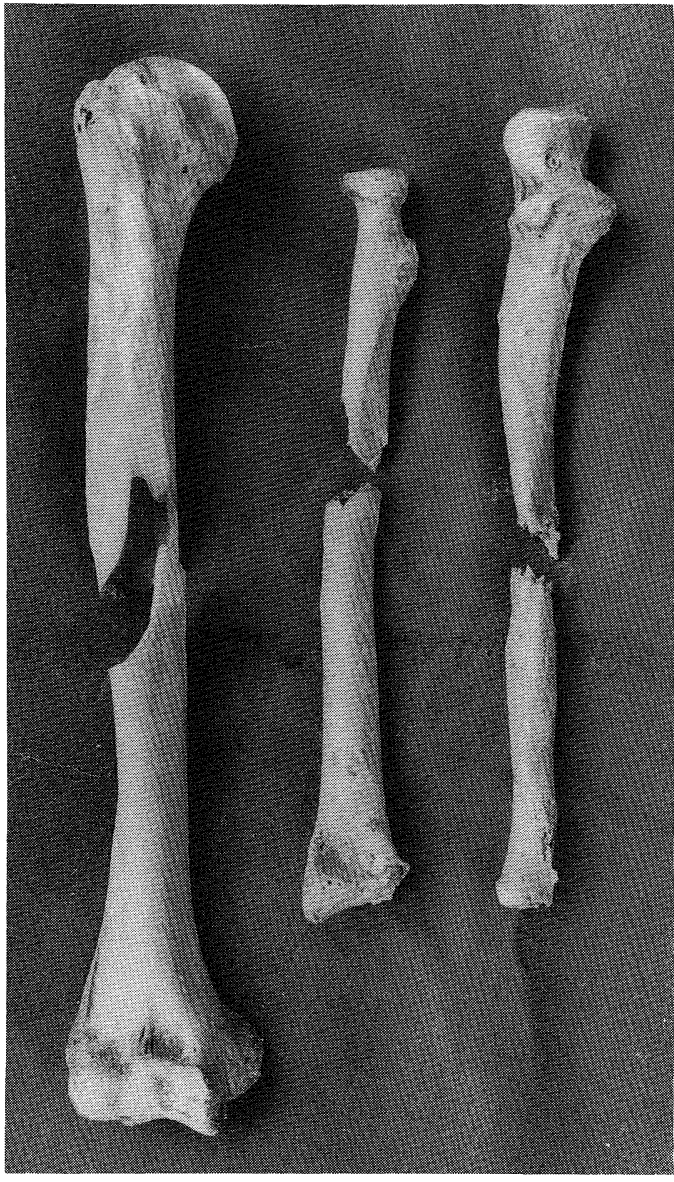

Fig. 8. Anterior view of the right humerus, radius and ulna fractured together in their shafts.

seen in the victim's skeleton seemed to be Japanese mediaeval physical traits. The victim had a noticeable deposit of dental calculus on his upper and lower teeth, suggesting that he had no custom to brush or clean his teeth with a toothbrush or tooth-pick. Although three lower incisor and a canine teeth had been lost antemortem probably due to their periodontal disease, no dental caries was found on the occlusal surfaces of the teeth. His molar teeth showed a marked degree of wear in contrast with the age given by both cranial suture closure and metamorphosis of the pubic symphyseal surfaces.
The present-day villagers of Kambara live within sight of Mt. Asama. They are considered to be directly descended from the old villagers of Kambara where large number of the inhabitants were killed by the 1783 volcanic eruption of this volcano. Those who were left there did not want to move away. They stayed at the buried village to have difficulty in rebuilding their homes and lives. Most people who lived in this relay station were fundamentally farmers. They have worked their land on the gentle slopes of the volcano for generations. They have kept the fields of crops and vegetables which they worked so hard to produce. They valued the volcano's advantages more than its risks. The volcanic soils were fertile, while springs from the mountain supplied irrigation water. The Kambara villagers at modern times hope that an eruption of Mt. Asama will not happen in their lifetime, but there is always a risk that they may die as a result of an explosive eruption. The main problem facing the villagers is how to catch an effective warning and how to make good their escape when danger threatens. How can they avoid the dangers? Knowing what might happen in the case of an eruption of Mt. Asama, making plans to themselves and their homes may help to cut down the risks. The present study has cleared up the actual situation of one of the human victims who were killed by the failure in their escape from the avalanche of volcanic debris caused by the violent eruption of Mt. Asama in 1783. It is to be hoped that this paper will be of help towards a way to avert a disaster from the future eruption of the volcano.

\section{Acknowledgement}

The author wishes to express his thanks to Mr. Eiji MATSUSHIMA for his generous welcome and great kindness as well as for his much help and collaboration in the course of these examinations. Thanks are also due to the cordial hospitality of the Board of Education of Tsumagoi Village, 
Gunma Prefecture, Japan.

抄 録

天明 3 年(1783)の浅間山大爆発による 1 犠牲者

森本岩太郎

日本は火山国であり，世界の活火山の約 $10 \%$ が集 中しているという。炎山爆発による犠牲者は多いが, その割りに犠牲者自身に関する発見報告は少ない。 浅間山 $(2,542 \mathrm{~m})$ は有名な火山で, 古来大爆発を繰り 返してきた. 浅間山の北麓にある群馬県吾妻郡嬬恋 村鎌原の旧鎌原宿は天明 3 年 (1783) 8 月 5 日の同山 大爆発による鎌原火砕流下に埋まり,93軒の民家が全 滅した。この大爆発は「天明の浅間焼け」と呼ばれ, 東日本における天明の飢饉を加速・増幅したという. 鎌原宿では,この爆発により村人597名のうち466名 （78\%）が死んだ。1976年に鎌原の十日ノ窪で犠牲者 の遺骨 2 個体（成人と小児）が偶然発見されたが, これは調べずに埋葬されたという，鎌原宿の惨状は， 1979年の浅間山麓埋没村落総合調查会による発掘調 查により初めて実際に明らかにされたが，そのおり 犠牲者の遺骨 3 個体（十日ノ窪で 1 体・镜音堂階段 下で 2 体）が出土した。十日ノ窪の遺骨は保存不良 であったが，段階下の遺骨は逃げ切れずに倒れた血 縁関係の女性 2 名と考えられている。著者は1987年 の嬬恋村当局による発掘調査により旧鎌原宿の延命 寺跡から新たに発見された 1 個体分の壮年期男性遺 骨を現地で調べた。寺で作業中に火砕流に襲われ，あ わてて飛び出して倒れたと思われる. 浅間山に足を 向けて俯臥位をとり, 顔面をやや左に回し, 左上肢・ 右下肢を上下に伸ばして, 右上肢, 左下肢を曲げて いた．身体の右後方から火砕流を受けたので, 伸び た右下肢は股関節でやや外転していた。 また，曲げ た右上肢は流れ落ちる石の直撃を受け, 上腕・橈 尺骨の 3 骨体が一緒に完全骨折を起こしていた。こ の男性は推定身長が約 $152 \mathrm{~cm}$ と小さいが，上・下肢 骨は頑丈である. 頭蓋長幅示数は長頭型に属し, 弱い 歯槽性突靧が見られる。骨年令の割に大臼歯の咬耗 が進んでいる. 下顎切歯 3 本が歯周症のため生前脱 落し，それらの歯槽は閉鎖している。䠛蝕は見られ ないが，上・下顎歯とも歯石の付着が著しい，第 9 $\sim 10$ 胸椎と第 $2 \sim 4$ 腰椎に変形性脊椎症があり, 左 肘関節に慢性関節炎像が認められる。旧鎌原宿出土
の天明 3 年の浅間山大爆発による犠牲者のうち, 比 較的詳しく調べられたのは, 本遺骨が 3 例目である.

\section{References}

ASAHI-SHIMBUN-SHA, 1987: Volcanic eruption of Mt. Asama, with consequent grievous famine. In: ShukanAsahi-Hyakka, Nihon no Rekishi, No. 87, Recent times II, Asahi-Shimbun-Sha, Tokyo, pp.8•2898•320. (In Japanese)

〔朝日新聞社, 1987 : 浅間山の噴火と飢饉, 週刊朝日 百科, 日本の歴史, No87 近世 II, 朝日新聞社, 東京, pp. $8 \cdot 289-8 \cdot 320$.]

ASAMA-SANROKU-MAIBOTSU-SONRAKU-SOGOCHOSA-KAI and TOKYO-SHIMBUN-HENSHUKYOKU- HODOBU (ed.), 1981: Tsumagoi, Nihon no Pompeii, Enlarged ed., Tokyo-Shimbun-Shuppankyoku, Tokyo, pp.1-213. (In Japanese)

〔浅間山麓埋没村落総合調查会・東京新聞編集局特 別報道部 (共編), 1981 : 嬬恋・日本のポンペイ, 増補版, 東京新聞出版局, 東京, pp. 1 -213.J

BROTHWELL, D.R., 1981: Digging up Bones. 3rd ed., British Museum (Natural History), Cornell Univ. Press, Ithaca, New York, pp.64-70.

GUNMA-BUNKA-NO-KAI, 1976: Kusatsu hot-spring and the skirts of Mt. Asama. In: Gunma-ken no Rekishi Sanpo, Zenkoku Rekishi Sanpo Series, No. 10, Yamakawa Shuppan-sha, Tokyo, pp.238-239. (In Japanese)

〔群馬文化の会, 1976 : 草津と浅間山麓, 群馬県の 歴史散歩, 全国歴史散歩シリーズ10. 山川出版社, 東京, pp.238-239.]

GUNMA-NO-REKISHI-MONOGATARI-KANKO-KAI (ed.), 1979: Tales of a heavy sandfall due to the volcanic activity of Mt. Asama in 1783. In: Gumma no Rekishi-Monogatari, Nippon-Hyojun Inc., Tokyo, pp.130-141. (In Japanese)

〔群馬の歴史ものがたり刊行会（編）, 1979 : 浅間焼 け砂降り記, 群馬の歴史ものがたり, 日本標準 (株)，東京, pp.130-141.J

HAGIWARA, S., 1975: On the great volcanic eruption of Mt. Asama in 1783. In: HAGIWARA Susumu Chosaku-Senshu; Asama-yama Fudoki, (Reprinted from the edition in 1942), Tosho-Kankokai, Tokyo, pp.12-39. (In Japanese)

〔萩原進, 1975 : 天明三年浅間山大噴火に就いて。 萩原進著作選集，浅間山風土記（復刻版，原本は 1942年刊), 図書刊行会, 東京, pp.12-39.]

KNAPP, B., 1989: World Disasters; Volcano. Macmillan, London, p.48. 
KODAMA, K., S. OISHI and Y. SAITO (ed.), 1989: Temmei San-nen Asama-yama Funka Shiryo-shu, Vols. 1 and 2. Univ. of Tokyo Press, Tokyo. (In Japanese)

〔児玉幸多・大石慎三郎・齋藤洋一 (編)，1989 : 天 明三年浅間山噴火史料集 - 上下巻. 東京大学出版 会, 東京.]

KOHARA, Y., T. NAKAMURA, T. NishizAWA and M. SUZUKI (1971): Human infant remains of the earliest Jomon period, suffering death by a falling rock. J. Anthrop. Soc. Nippon, 79: 55-60. (In Japanese with English summary)

KOIZUMI, H., 1986: A village buried under the volcanic debris. In: Tsuboi, K. (ed.) Zusetsu: Hakkutsu ga Kataru Nihon-shi, Vol. 2, Kanto and Ko-Shinetsu Chiho, VI. Kamakura to Edo period. Shin-JimbutsuOrai-Sha, Tokyo, pp.275-280. (In Japanese)

〔古泉弘, 1986 : 噴火に埋むれた村. 坪井清足（監 修), 図説・発掘が語る日本史, 第 2 巻, 関東・甲 信越編, VI. 鎌倉 - 江戸時代. 新人物往来社, 東京, pp. $275-280$.

NAKAMURA, K., T. MATSUDA and I. MORIYA, 1987: Mt. Asama and its violent eruption in 1783. In: Kaizuka, S. et al. (ed.), Nihon no Shizen Vol. 1, Japanese Islands with Volcanoes and Earthquakes, 5. Volcanoes and Earthquakes in Jo-Shin-etsu Region. Iwanami Shoten, Tokyo, pp.190-200. (In Japanese) 〔中村一明・松田時彦・守屋以智雄, 1987 : 浅間山 と天明の大噴火. 貝塚爽平ほか（編），日本の自然 第 1 巻, 火山と地震の国, 5 . 上信越地域の火山 と地震. 岩波書店, 東京, pp.190-200.]

NOTO, T., 1988: Rice fields and villages buried under volcanic ash in Gunma Prefecture. In: Shukan Asahi
Hyakka, Japanese History, Separated volume, The Way of Reading History, 3. Invitation to Archaeology. Asahi-Shimbun-Sha, Tokyo, pp.27-32. (In Japanese) 〔能登健, 1988 : 火山灰の下から一群馬県の埋没水 田とムラ, 週刊朝日百科, 日本の歴史, 別冊, 歴 史の読み方 3 , 考古学への招待. 朝日新聞社, 東 京, pp.27-32.]

ODA, E., 1988: Gigantic explosion of Volcano Asama in 1783. In: Y. AOKI (ed.), Manga Gunma no Rekishi Vol. 4, Recent Times, II. Jomo-Shimbun-Sha, Maebashi, pp.30-51. (In Japanese)

〔小田悦望, 1988 : 天明の浅明焼け. 青木裕 (監修), まんが群馬の歴史, 第 4 巻, 近世編 II. 上毛新聞 社, 前橋, pp.30-51.]

OISHI, S., 1986: Temmei San-nen Asama Dai-Funka: Nihon no Pompeii Kambara-mura Hakkutsu, Kadokawa-Sensho No. 174. Kadokawa Shoten, Tokyo. (In Japanese)

〔大石慎三郎, 1986 : 天明三年浅間大爆発. 日本の ポンペイ鎌原村発掘, 角川選書174. 角川書店, 東 京.J

OISHI, S., 1990: Kambara village buried, compared to Pompeii in Italy. Rekishi-Dokuhon, 35(12): 100-107. (In Japanese)

〔大石慎三郎， 1990 : 鎌原村 ; 埋もれた “日本のポ ンペイ”。歴史読本, 35(12) : 100-107.J

READER's DIGEST ASSOCIATION (ed.), 1973: Reader's Digest History of Man; The Last Two Million Years. Reader's Digest Association, London, p.119.

TIMES BOOKS (ed.), 1988: Past Worlds; The Times Atlas of Archaeology. Times Books, London, pp.176-177.

\section{森 本 岩 太 郎聖マリアンナ医科大学第 2 解剖学教室 \\ 干216 川崎市宮前区菅生 2-16-1}

Iwataro MORIMOTO

Department of Anatomy, St. Marianna University School of Medicine

2-16-1 Sugao, Miyamae, Kawasaki, Kanagawa 216, Japan 